\title{
A GEOCHEMICAL INVESTIGATION OF SOILS, APPLES AND LEAVES IN AGIA AREA, CENTRAL GREECE
}

\author{
Skordas K. ${ }^{1}$, Papastergios G. ${ }^{2}$, Filippidis A. ${ }^{2}$ and Kantiranis N. ${ }^{2}$ \\ ${ }^{1}$ University of Thessaly, Department of Ichthyology and Aquatic Environment, Fitokou St., N. \\ Ionia 38446, Greece, kskord@uth.gr \\ ${ }^{2}$ Aristotle University of Thessaloniki, Department of Mineralogy-Petrology-Economic Geology, \\ 131 Egnatia St. Thessaloniki 54124, Greece, gpapaste@geo.auth.gr
}

\begin{abstract}
Forty two soil, apple and leaf samples from Agia area, central Greece, were collected and analyzed for their content in 7 major elements ( $\mathrm{Ca}, \mathrm{Fe}, \mathrm{K}, \mathrm{Mg}, \mathrm{Na}, \mathrm{P}$ and $\mathrm{S}$ ). The average concentration of the determined elements follows the order: concentration in soils > concentration in leaves > concentration in apples. Elements, such as Fe that is found enriched in the soils of the study area, due to local geology, is not correlated with its concentrations in apples and leaves, possibly because of its association with resistant minerals. On the other hand, the relationship of some elements (i.e., $K, P, S$ ) that are constituents of the agrochemicals applied in the area, indicate that they are more readily available by the trees, either because they are associated with less resistant (clay) minerals, or because they derive through the application of agrochemical products (i.e., phosphate fertilisers, fungicides etc.).
\end{abstract}

Keywords: mobility of chemical element, environment, fertilizer, agrochemical.

\section{Пєрíi $\eta \psi \eta$}

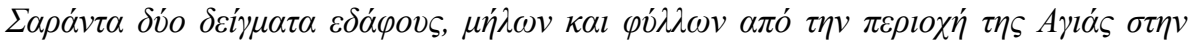

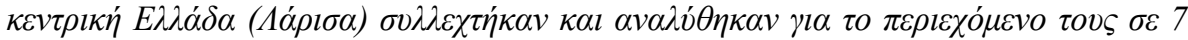

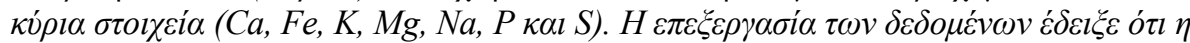

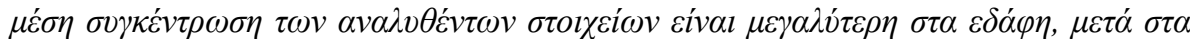

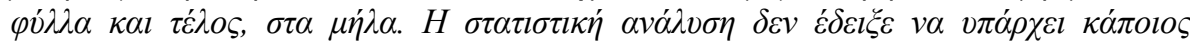

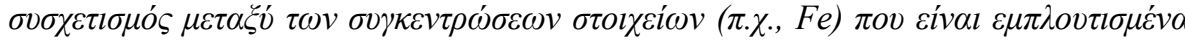

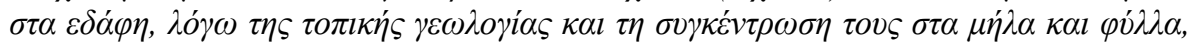

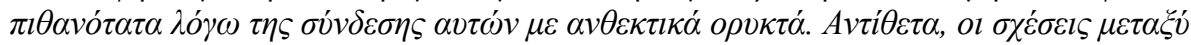

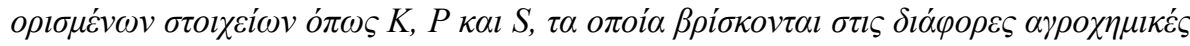

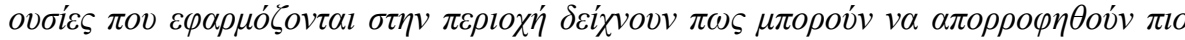

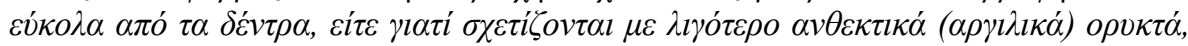

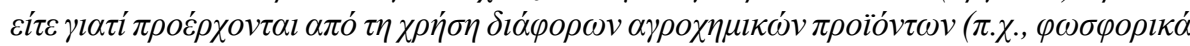
$\lambda \imath \pi \alpha ́ \sigma \mu \alpha \tau \alpha, \zeta \zeta \zeta \alpha v \imath o \kappa \tau o ́ v \alpha \kappa \lambda \pi$.).

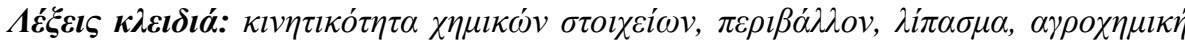
ovoía.

\section{Introduction}

Trees and plants and, consequently, their fruits and leaves, may contain and/or accumulate chemical elements depending on several attributes (i.e., soil chemical content, area of cultivation, method of 
cultivation, individual fruit/plant properties and others), contributing this way to the daily need of humans in such nutrients (Wagner, 1993; Bobrowska-Grzesik and Jakobik-Kolon 2008; Skordas et al., 2013). Some of these elements are called "macronutrients" (i.e., Ca, Fe, K, P etc.). They are considered as essential, or at least more essential than others, to the life cycles of organisms and are absorbed by them in significant amounts (Kabata-Pendias and Pendias, 2001).

At the same time, soils enriched in chemical elements, either through natural factors or through manmade procedures could be considered as an additional aspect to the problem as they could pass through it to fruits consumed by humans. The content of chemical elements in soils is highly affected and differentiated by the nature of parent materials (Kelepertsis et al., 2001; Skordas and Kelepertsis, 2005; Papastergios et al., 2009, 2010, 2011; Petrotou et al., 2010, 2012; Skordas et al., 2013). The latter controls, along with other factors (i.e., soil $\mathrm{pH}, \mathrm{Eh}$, absorptive power of soil constituents etc.) the level of the element availability and their uptake from plants and animals in sufficient and, in some cases, even toxic levels (Alloway et al., 1988; Alloway, 1995; Hesterberg, 1998; KabataPendias and Pendias, 2001; Newman and Unger, 2003).

The aim of the present research was to study the concentrations of seven major elements $(\mathrm{Ca}, \mathrm{Fe}, \mathrm{K}$, $\mathrm{Mg}, \mathrm{Na}, \mathrm{P}, \mathrm{S}$ ) as well as, investigate the relationship between the content of these elements in soils, apples and leaves from Agia area, Thessaly, central Greece. This research advances the knowledge offered by a previous work (Skordas et al., 2013) as it examines the interrelationships between three means (soils, apples and leaves), contrary to the previous one which offered data and analysis only for two (soils and apples).

\section{Materials and Methods}

\subsection{Study area - Geological setting}

The study area is located in the eastern part of the Regional Unit of Larissa, central Greece (Fig. 1). It is a region with a plain relief that is surrounded by low hills in the eastern and southern part. The large plain of Larissa lies to the west of the studied area. Most part of the surface is covered by apple tree orchards, while a large portion of the mountainous area and the hills are covered by mountainous forest.

The area consists of metamorphic rocks, belonging to the Pelagonian zone. The main geologic formations are (Skordas and Kelepertsis, 2005; Skordas et al., 2010, 2013): Quaternary sediments, Neogene sediments, marbles, metamorphic rocks (i.e., gneisses-schists, amphibolite schists, amphibolites) and ophiolites.

Because of the extensive cultivation several agricultural products such as fertilizers and agrochemicals (i.e., pesticides, fungicides and insecticides) are applied. Some of the most common substances used are chlorpyrifos, diflubenzuron, dithianon, flufenoxuron, myclobutanil, paraffin oil, phosmet, pyriproxyfen, thiacloprid, copper oxychloride, sulphur etc. These substances are applied to the orchards most commonly between March and September, but sometimes application could take place all year long. Fertilizer application usually happens during January, while the fruits are harvested around September.

\subsection{Sampling, sample preparation and methods}

A total of 42 samples from each sample type (soil, apple, leaf) were collected covering an area of $65 \mathrm{~km}^{2}$, approximately. During the sampling procedure the initial regular sampling grid of 500x500 $\mathrm{m}$ was impossible to follow accurately, because of the cultivated and, in some parts, mountainous terrain. However, care was taken to preserve a uniform distribution of sampling sites over the study area (Fig. 1). In the case of the apples and leaves, the samples were collected from the apple tree that was nearest to the location of the soil sample. A more detailed description of the sampling and treatment procedure is described in Skordas et al. (2013). Soil samples were analyzed for their elemental content by Inductively Coupled Plasma - Atomic Emission Spectrometry (ICP-AES), 
while for the apples and leaves Inductively Coupled Plasma - Mass Spectrometry (ICP-MS) was used.

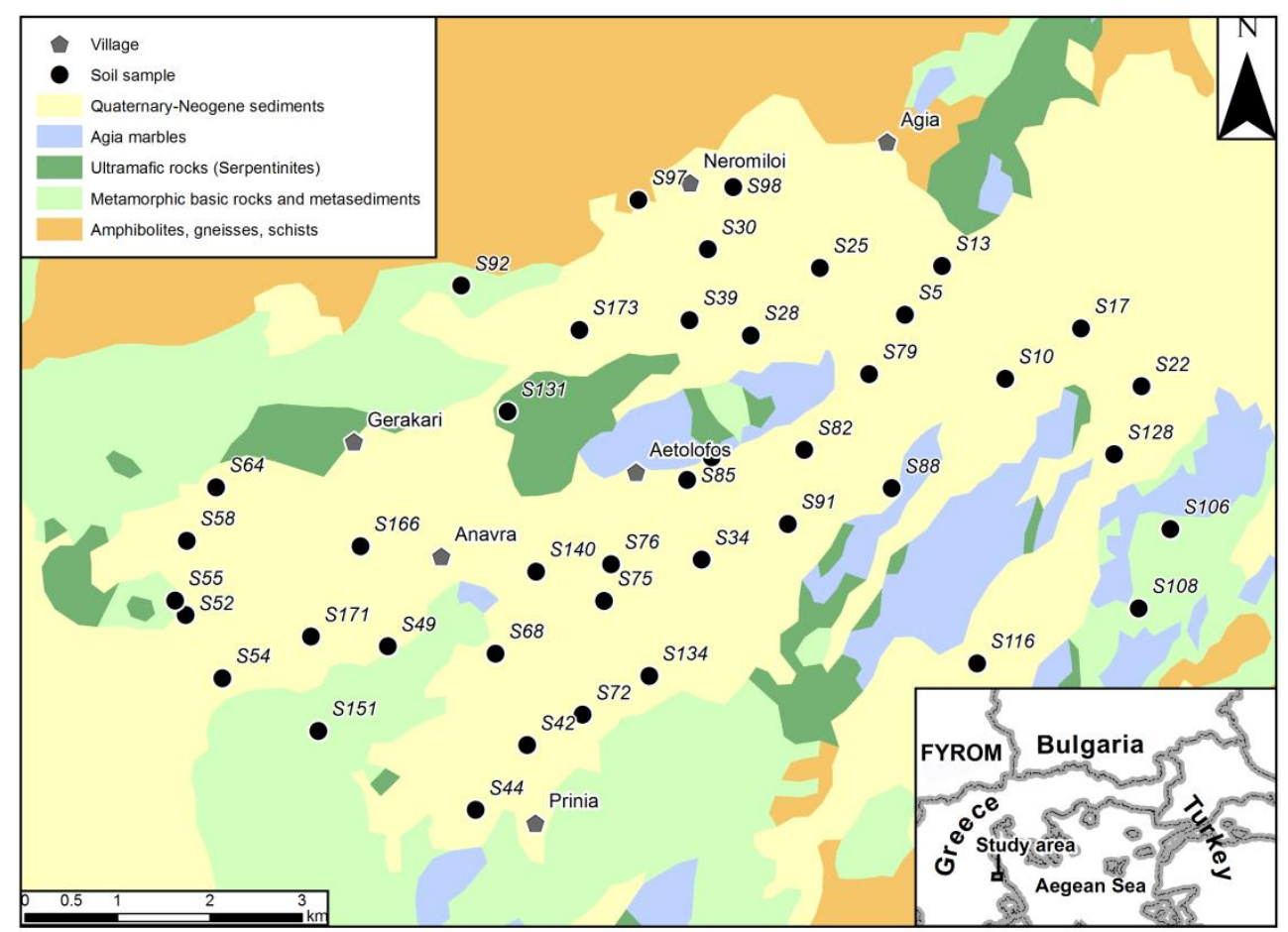

Figure 1 - Simplified geological map of the study area and sample locations (modified after Skordas et al., 2013).

\section{Results and Discussion}

Descriptive statistics regarding the elements determined in the present study are given in Table 1. The most abundant element in soil is $\mathrm{Fe}$, followed by $\mathrm{Ca}, \mathrm{Mg}, \mathrm{Na}, \mathrm{K}$ and $\mathrm{P}$. The rather elevated concentrations of $\mathrm{Fe}$ and $\mathrm{Mg}$, were expected, as in the study area ophiolitic (ultramafic) rocks, which contain the above mentioned elements in noteworthy amounts, are present (Skordas and Kelepertsis, 2005; Petrotou et al., 2010, 2012; Skordas et al., 2010, 2013). A study (Kelepertzis, 2014) regarding agrcultural soils in Argolida, Greece, has reported slightly different average concentrations for $\mathrm{Fe}$, $\mathrm{P}$ and $\mathrm{K}$ (27100 $\mathrm{mg} \mathrm{kg}^{-1}, 3000 \mathrm{mg} \mathrm{kg}^{-1}$ and $900 \mathrm{mg} \mathrm{kg}^{-1}$, respectively).

In apples, the most abundant element is $\mathrm{K}$, followed by $\mathrm{P}, \mathrm{Mg}, \mathrm{Ca}, \mathrm{S}, \mathrm{Na}$ and $\mathrm{Fe}$, while in leaves $\mathrm{Ca}$ is the element with the largest average concentration, followed by $\mathrm{K}, \mathrm{Mg}, \mathrm{P}, \mathrm{S}, \mathrm{Fe}$ and $\mathrm{Na}$.

\subsection{Overall assessment}

For the majority of the determined elements their average concentrations follow the order: concentration in soils > concentration in leaves > concentration in apples (Table 1, Fig. 2). The same behaviour is demonstrated by the rest of the calculated statistic parameters, as well (Table 1). However, $\mathrm{P}$ is an exception to this behaviour. Its average concentration in soils $\left(1119 \mathrm{mg} \mathrm{kg}^{-1}\right)$ is about the same as in apples $\left(881.7 \mathrm{mg} \mathrm{kg}^{-1}\right)$ and lower than in leaves $\left(2073 \mathrm{mg} \mathrm{kg}^{-1}\right)$. This could be a result of the excessive application of phosphoric fertilizers or/and organophosphate agrochemicals such as chlorpyrifos $\left(\mathrm{C}_{9} \mathrm{H}_{11} \mathrm{C}_{13} \mathrm{NO}_{3} \mathrm{PS}\right)$ and phosmet $\left(\mathrm{C}_{11} \mathrm{H}_{12} \mathrm{NO}_{4} \mathrm{PS}_{2}\right)$. It also can be deducted that, probably, the determined elements accumulate more in leaves than in fruits (apples). 
Table 1 - Descriptive statistics regarding the elements determined in soils, apples and leaves.

\begin{tabular}{|c|c|c|c|c|c|c|}
\hline$\left(\mathrm{mg} \mathrm{kg}^{-1}\right)$ & Soil & Leaf & Apple & Soil & Leaf & Apple \\
\hline Element & \multicolumn{3}{|c|}{$\mathrm{Ca}$} & \multicolumn{3}{|c|}{$\mathbf{F e}$} \\
\hline median & 25250 & 16350 & 400.0 & 45300 & 195.0 & 15.0 \\
\hline average & 25390 & 16860 & 390.5 & 46486 & 228.1 & 28.3 \\
\hline geomean & 23813 & 16593 & 383.5 & 45916 & 208.4 & 19.4 \\
\hline minimum & 11600 & 11400 & 300.0 & 31200 & 110.0 & 10.0 \\
\hline maximum & 70400 & 25700 & 600.0 & 65200 & 690.0 & 150.0 \\
\hline std deviation & 10117 & 3078 & 75.9 & 7364 & 112.9 & 31.5 \\
\hline Element & \multicolumn{3}{|c|}{$\mathbf{K}$} & \multicolumn{3}{|c|}{ Mg } \\
\hline median & 13950 & 11800 & 9550 & 20250 & 4935 & 480.0 \\
\hline average & 13543 & 11964 & 9676 & 20088 & 5052 & 474.8 \\
\hline geomean & 13303 & 11713 & 9545 & 19557 & 4976 & 470.8 \\
\hline minimum & 8300 & 6600 & 6000 & 9900 & 3590 & 360.0 \\
\hline maximum & 17300 & 16500 & 14700 & 32700 & 7440 & 610.0 \\
\hline std deviation & 2448 & 2409 & 1632 & 4633 & 907.3 & 62.3 \\
\hline Element & \multicolumn{3}{|c|}{$\mathrm{Na}$} & \multicolumn{3}{|c|}{$\mathbf{P}$} \\
\hline median & 15100 & 80.0 & 40.0 & 975.0 & 2040 & 865.0 \\
\hline average & 14924 & 89.8 & 42.1 & 1119 & 2073 & 881.7 \\
\hline geomean & 14629 & 83.8 & 40.5 & 1019 & 2043 & 869.4 \\
\hline minimum & 8800 & 50.0 & 30.0 & 430.0 & 1410 & 590.0 \\
\hline maximum & 23900 & 250.0 & 90.0 & 4290 & 3440 & 1190 \\
\hline std deviation & 3040 & 37.9 & 13.2 & 619.4 & 378.5 & 148.3 \\
\hline Element & & \multicolumn{2}{|c|}{$\mathbf{S}$} & & & \\
\hline median & & 1900 & 300.0 & & & \\
\hline average & & 1874 & 302.4 & & & \\
\hline geomean & & 1862 & 245.3 & & & \\
\hline minimum & & 1500 & 50.0 & & & \\
\hline maximum & & 2400 & 800.0 & & & \\
\hline std deviation & & 213.1 & 181.1 & & & \\
\hline
\end{tabular}

Phosphate fertilizers are considered as an important source of heavy metals entering agricultural soils (Nicholson et al., 2003; Rodriguez Martin et al., 2006). Other elements (heavy metals) are also present in varying amounts in other inorganic fertilizers (i.e., nitrogen, potash) and in liming materials (Nicholson et al., 2003; Rodriguez Martin et al., 2006). The excessive application of such substances could lead to elevated concentrations in agricultural products cultivated over these soils (Otte et al., 1993; Dudka et al., 1994; Rodriguez Martin et al., 2006; Skordas et al., 2013). Hence, the elevated values of such elements in the apples of the present study could derive from the excessive amounts of fertilizers and agrochemicals applied to the local crops. 


\subsection{Elemental relationships between the sampled means}

Additionally, correlation analysis was carried out to determine the nature of the relationships between the investigated elements. Because the data of the present research were not normally distributed the estimation of Spearman's rank correlation coefficient (also known as Spearman's rho) was selected (non-parametric statistics). Unless otherwise stated, correlations were considered significant at $\mathrm{p}<0.01$.

In soils, elements that are significantly correlated are $\mathrm{Na}$ and $\mathrm{Ca}(\mathrm{r}: 0.52), \mathrm{Fe}$ and $\mathrm{Mg}$ (r: 0.40$)$ and $\mathrm{P}$ and $\mathrm{Ca}$ (r: 0.52) (Table 2). In apples (Table 3), the latter correlation applies for $\mathrm{K}$ and $\mathrm{Mg}$ (r: 0.61 ) and $\mathrm{K}$ and $\mathrm{P}$ (r: 0.44), while a correlation (at the 0.05 level) is also displayed by $\mathrm{Ca}$ and $\mathrm{Mg}$ ( $\mathrm{r}: 0$. 32) and $\mathrm{Mg}$ and $\mathrm{P}$ (r: 0.36). Finally, in leaves (Table 4), the only correlation present is between $\mathrm{K} \mathrm{a}$ nd $\mathrm{Mg}(\mathrm{r}:-0.36)$, which, is negative $(\mathrm{p}<0.05)$.

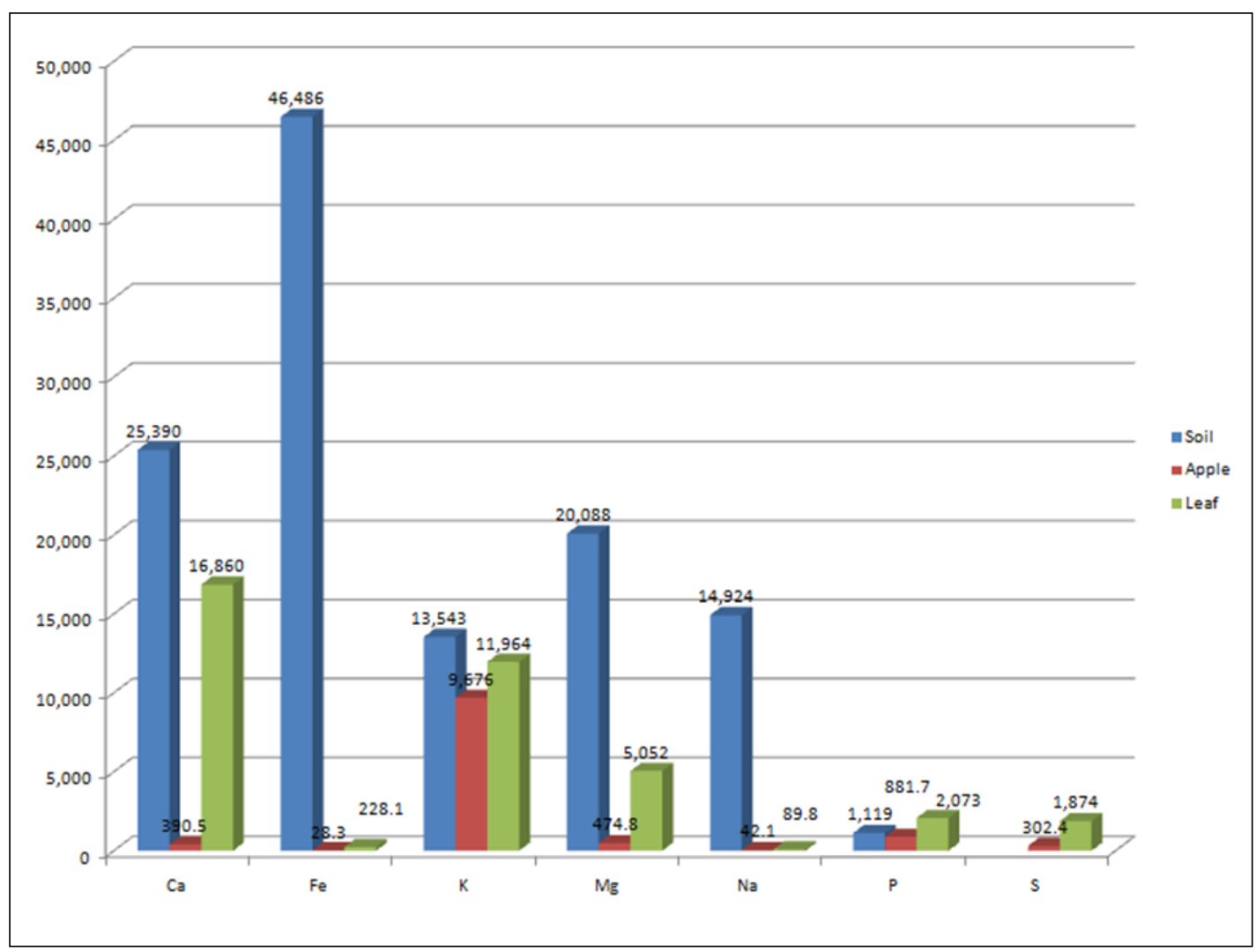

Figure 2 - Graphical representation of the average elemental concentrations determined in soils, apples and leaves. 
Table 2 - Spearman's rank correlation coefficient (Spearman's rho) for the determined elements in soils (S) and apples (A).

\begin{tabular}{|c|c|c|c|c|c|c|c|c|c|c|c|c|}
\hline & $\mathrm{Ca}_{S}$ & $C a_{A}$ & $\mathrm{Fe}_{S}$ & $F e_{A}$ & $K_{S}$ & $K_{A}$ & $M g_{S}$ & $M g_{A}$ & $N a_{S}$ & $N a_{A}$ & $P_{S}$ & $P_{A}$ \\
\hline $\mathrm{Ca}_{\mathrm{s}}$ & 1 & & & & & & & & & & & \\
\hline $\mathrm{Ca}_{\mathrm{A}}$ & -.242 & 1 & & & & & & & & & & \\
\hline $\mathrm{Fe}_{\mathrm{S}}$ & .111 & .137 & 1 & & & & & & & & & \\
\hline $\mathrm{Fe}_{\mathrm{A}}$ & -.004 & -.231 & -.134 & 1 & & & & & & & & \\
\hline $\mathrm{K}_{\mathrm{S}}$ & -.175 & .112 & -.133 & -.104 & 1 & & & & & & & \\
\hline $\mathrm{K}_{\mathrm{A}}$ & .170 & -.021 & .119 & -.064 & -.054 & 1 & & & & & & \\
\hline $\mathrm{Mg}_{\mathrm{S}}$ & .120 & -.049 & $.401 * *$ & .070 & .174 & .012 & 1 & & & & & \\
\hline $\mathrm{Mg}_{\mathrm{A}}$ & -.145 & $.316^{*}$ & -.002 & -.105 & -.206 & $.612 * *$ & -.164 & 1 & & & & \\
\hline $\mathrm{Nas}_{\mathrm{s}}$ & $.520 * *$ & -.201 & .010 & $.363^{*}$ & -.198 & .183 & -.045 & -.103 & 1 & & & \\
\hline $\mathrm{Na}_{\mathrm{A}}$ & -.057 & -.011 & -.270 & -.050 & -.129 & .051 & -.159 & .146 & -.025 & 1 & & \\
\hline $\mathrm{P}_{\mathrm{S}}$ & $.525 * *$ & -.049 & .110 & .027 & -.078 & .229 & .099 & .089 & .268 & -.154 & 1 & \\
\hline $\mathrm{P}_{\mathrm{A}}$ & .162 & -.034 & -.203 & .108 & -.226 & $.441 * *$ & -.154 & $.356^{*}$ & $.370^{*}$ & .159 & .002 & 1 \\
\hline
\end{tabular}

**. Correlation is significant at the 0.01 level (2-tailed).

*. Correlation is significant at the 0.05 level (2-tailed). 
Table 3 - Spearman's rank correlation coefficient (Spearman's rho) for the determined elements in soils (S) and leaves (L).

\begin{tabular}{|c|c|c|c|c|c|c|c|c|c|c|c|c|}
\hline & $C a_{S}$ & $C a_{L}$ & $\mathrm{Fe}_{S}$ & $F e_{L}$ & $K_{S}$ & $K_{L}$ & $M g_{S}$ & $M g_{L}$ & $N a_{S}$ & $N a_{L}$ & $P_{S}$ & $P_{L}$ \\
\hline $\mathrm{Ca}_{\mathrm{S}}$ & 1 & & & & & & & & & & & \\
\hline $\mathrm{Ca}_{\mathrm{L}}$ & .209 & 1 & & & & & & & & & & \\
\hline $\mathrm{Fe}_{\mathrm{S}}$ & .111 & .006 & 1 & & & & & & & & & \\
\hline $\mathrm{Fe}_{\mathrm{L}}$ & .011 & -.139 & -.168 & 1 & & & & & & & & \\
\hline $\mathrm{K}_{\mathrm{S}}$ & -.175 & .073 & -.133 & .211 & 1 & & & & & & & \\
\hline $\mathrm{K}_{\mathrm{L}}$ & -.003 & -.256 & -.071 & -.001 & .059 & 1 & & & & & & \\
\hline $\mathrm{Mg}_{\mathrm{S}}$ & .120 & .167 & $.401 * *$ & .015 & .174 & -.006 & 1 & & & & & \\
\hline $\mathrm{Mg}_{\mathrm{L}}$ & $.310^{*}$ & .226 & -.126 & .171 & -.224 & $-.362 *$ & .010 & 1 & & & & \\
\hline $\mathrm{Na}_{\mathrm{S}}$ & $.520 * *$ & .008 & .010 & .035 & -.198 & -.033 & -.045 & -.061 & 1 & & & \\
\hline $\mathrm{Na}_{L}$ & .248 & .097 & .050 & .225 & -.058 & -.299 & -.009 & .232 & .249 & 1 & & \\
\hline $\mathrm{P}_{\mathrm{S}}$ & $.525 * *$ & .043 & .110 & .159 & -.078 & .156 & .099 & -.004 & .268 & .016 & 1 & \\
\hline $\mathrm{P}_{\mathrm{L}}$ & -.015 & -.120 & -.229 & .015 & .013 & .191 & -.038 & -.129 & .127 & .025 & $-.316^{*}$ & 1 \\
\hline
\end{tabular}


Table 4 - Spearman's rank correlation coefficient (Spearman's rho) for the determined elements in leaves (L) and apples (A).

\begin{tabular}{|c|c|c|c|c|c|c|c|c|c|c|c|c|c|c|}
\hline & $C a_{L}$ & $C a_{A}$ & $F e_{L}$ & $F e_{A}$ & $K_{L}$ & $K_{A}$ & $M g_{L}$ & $M g_{A}$ & $N a_{L}$ & $N a_{A}$ & $P_{L}$ & $P_{A}$ & $S_{L}$ & $S_{A}$ \\
\hline $\mathrm{Ca}_{\mathrm{L}}$ & 1 & & & & & & & & & & & & & \\
\hline $\mathrm{Ca}_{\mathrm{A}}$ & -.022 & 1 & & & & & & & & & & & & \\
\hline $\mathrm{Fe}_{\mathrm{L}}$ & -.139 & -.175 & 1 & & & & & & & & & & & \\
\hline $\mathrm{Fe}_{\mathrm{A}}$ & .161 & -.231 & $.350 *$ & 1 & & & & & & & & & & \\
\hline $\mathrm{K}_{\mathrm{L}}$ & -.256 & -.146 & -.001 & -.243 & 1 & & & & & & & & & \\
\hline $\mathrm{K}_{\mathrm{A}}$ & -.057 & -.021 & .145 & -.064 & $.517 * *$ & 1 & & & & & & & & \\
\hline $\mathrm{Mg}_{\mathrm{L}}$ & .226 & -.052 & .171 & .162 & $-.362^{*}$ & -.110 & 1 & & & & & & & \\
\hline $\mathrm{Mg}_{\mathrm{A}}$ & -.265 & $.316^{*}$ & .241 & -.105 & .261 & $.612 * *$ & -.083 & 1 & & & & & & \\
\hline $\mathrm{Na}_{\mathrm{L}}$ & .097 & .027 & .225 & .165 & -.299 & .005 & .232 & .001 & 1 & & & & & \\
\hline $\mathrm{Na}_{\mathrm{A}}$ & -.041 & -.011 & -.068 & -.050 & -.007 & .051 & .160 & .146 & $.369 *$ & 1 & & & & \\
\hline $\mathrm{P}_{\mathrm{L}}$ & -.120 & .025 & .015 & .120 & .191 & -.216 & -.129 & -.158 & .025 & .208 & 1 & & & \\
\hline $\mathrm{P}_{\mathrm{A}}$ & -.107 & -.034 & .226 & .108 & .152 & $.441 * *$ & .066 & $.356^{*}$ & .066 & .159 & $.366^{*}$ & 1 & & \\
\hline $\mathrm{S}_{\mathrm{L}}$ & -.196 & -.026 & .237 & -.198 & .300 & .097 & $-.416^{* *}$ & .257 & -.132 & .161 & .072 & -.222 & 1 & \\
\hline$S_{A}$ & -.049 & -.108 & .290 & .143 & .264 & .194 & -.069 & .172 & $-.325^{*}$ & $-.360 *$ & .009 & .109 & .159 & 1 \\
\hline
\end{tabular}


Nevertheless, when examining the elemental relationships amongst the different sampling in general, no significant correlation was found among the concentrations that the studied elements have in soils and apples, and in soils and leaves (Tables 2 and 3), indicating that for the studied elements their concentrations in apples and leaves is not strongly influenced by their concentration in soils. One would expect that, since these trees grow on soil enriched in Fe its elevated concentrations would be directly associated with their geogenic origin. Possibly, because Fe is found in resistant minerals is not readily available (Megremi, 2010; Petrotou et al., 2010).

However, strong correlations between the concentrations of $\mathrm{K}$ and $\mathrm{Mg}$, as well of $\mathrm{Fe}, \mathrm{Na}$ and $\mathrm{S}$ (at $\mathrm{p}<0.05$ ), in apples and leaves has been noted (Table 4). Elements (i.e., $\mathrm{Na}, \mathrm{Ca}$ ) that are associated with clay minerals, such as montmorillonite, could be more easily extracted from the trees and accumulate in different parts, thus, the existing correlation between this elements in apples and leaves. Another way for this elements to accumulate in apples and leaves could be through the application of the various agrochemical substances applied, as the strong correlation between $\mathrm{P}$ and Na implies (Table 4).

\section{Conclusions}

The treatment of the data presented in this research has shown that the average concentration of the determined elements follows the order: concentration in soils > concentration in leaves > concentration in apples. Elements, such as Fe that is found enriched in the soils of the study area is not correlated with its concentrations in apples and leaves, possibly due to its association with resistant minerals. On the other hand, the relationship of some elements (i.e., K, P, S) that are constituents of the agrochemicals applied in the area, indicate that they are more readily available by the trees, either because they are associated with less resistant (clay) minerals, or because they derive through the application of agrochemical products (i.e., phosphate fertilisers, fungicides etc.).

\section{References}

Alloway, B.J., 1995. Heavy Metals in Soils, $2^{\text {nd }}$ ed. Blackie, Glasgow.

Alloway, B.J., Thornton, I. and Smart, G.A., 1988. Metal availability, Sci. Total Environ., 75, 4169.

Bobrowska-Grzesik, E. and Jakobik-Kolon, A., 2008. Leaching of cadmium and lead from dried fruits and fruit teas to infusions and decoctions, J. Food Compost. Anal., 21, 326-331.

Dudka, S., Piotrowska, M. and Chlopecka, A., 1994. Effect of elevated concentrations of Cd and Zn in soil on spring wheat yield and the metal contents of the plants, Water Air Soil Pollut., 76, 333-341.

Hesterberg, D., 1998. Biogeochemical cycles and processes leading to changes in mobility of chemicals in soils, Agric. Ecosyst. Environ., 67, 121-133.

Kabata-Pendias, A. and Pendias, H., 2001. Trace elements in Soils and Plants, $3^{\text {rd }}$ ed. CRC Press, New York.

Kelepertsis, A., Alexakis, D. and Kita, I., 2001. Environmental geochemistry of soils and waters of Susaki area, Korinthos, Greece, Environ. Geochem. Health, 23, 117-135.

Kelepertzis, E., 2014. Accumulation of Heavy Metals in Agricultural Soils of Mediterranean: Insights from Argolida Basin, Peloponnese, Greece, Geoderma, 221-222, 82-90.

Megremi, I., 2010. Distribution and bioavailability of $\mathrm{Cr}$ in central Euboea, Greece, Central Eur. J. Geosciences, 2, 103-123.

Newman, M. and Unger, M., 2003. Fundamentals of Ecotoxicology, $2^{\text {nd }}$ ed., Lewis Publishers.

Nicholson, F.A., Smith, S.R., Alloway, B.J., Carlton-Smith, C. and Chambers, B.J., 2003. An inventory of heavy metals inputs to agricultural soils in England and Wales, Sci. Total Environ., 311, 205-219.

Otte, M.L., Haarsma, M.S., Broekman, R.A. and Rozema, J., 1993. Relation between heavy metal concentrations and salt marsh plants and soil, Environmental Pollution, 82, 13-22. 
Papastergios, G., Fernandez-Turiel, J.L., Georgakopoulos, A. and Gimeno, D., 2009. Natural and anthropogenic effects on the sediment geochemistry of Nestos River, northern Greece, Environmental Geology, 58(6), 1361-1370.

Papastergios, G., Fernandez-Turiel, J.L., Georgakopoulos, A. and Gimeno, D., 2010. Arsenic background concentrations in surface soils of Kavala area, northern Greece, Water, Air Soil Poll., 209(1), 323-331.

Papastergios, G., Filippidis, A., Fernandez-Turiel, J.L., Gimeno, D. and Sikalidis, C., 2011. Surface soil geochemistry for environmental assessment in Kavala area, northern Greece, Water Air Soil Pollut., 216, 141-152.

Petrotou, A., Skordas, K., Papastergios, G. and Filippidis, A., 2010. Concentrations and bioavailability of potentially toxic elements in soils of an industrialised area of northwestern Greece, Fresen. Environ. Bull., 19, 2769-2776.

Petrotou, A., Skordas, K., Papastergios, G. and Filippidis, A., 2012. Factors affecting the distribution of potentially toxic elements in surface soils around an industrialized area of northwestern Greece, Environ. Earth Sci., 65, 823-833.

Rodriguez Martin, J.A., Lopez Arias, M. and Grau Corbi, J.M., 2006. Heavy metals contents in agricultural topsoils in the Ebro basin (Spain). Application of the multivariate geoestatistical methods to study spatial variations, Environmental Pollution, 144, 1001-1012.

Skordas, K. and Kelepertsis, A., 2005. Soil contamination by toxic metals in the cultivated region of Agia, Thessaly, Greece. Identification of sources of contamination, Environmental Geology, 48, 615-624.

Skordas, K., Pateras, D., Papastergios, G., Lolas, A. and Filippidis, A., 2010. Spatial distribution and concentrations of $\mathrm{Fe}, \mathrm{Mg}, \mathrm{Co}, \mathrm{Cr}$ and $\mathrm{Ni}$ in surface soils of central Greece as affected by parent rocks, Geochemistry, Mineralogy and Petrology, Sofia, 48, 95-102.

Skordas, K., Papastergios, G. and Filippidis, A., 2013. Major and trace elements contents in apples from a cultivated area of central Greece, Environ. Monit. Assess., 185, 8465-8471.

Wagner, G.J., 1993. Accumulation of cadmium in crop plants and its consequences to human health, Adv. Agron., 51, 173-212. 